\section{Early antibiotic from a cranberry bog}

Losee Ling and colleagues refer to Selman Waksman's "platform of natural product drug discovery" (Nature 517, 455-459; 2015; see also K. Lewis Nature 485, 439-440; 2012), which alludes to Waksman's 1943 discovery from soil of streptomycin, the first drug effective against tuberculosis. In fact, René Dubos, Waksman's former student, had isolated the first antibiotic from soil bacteria more than a decade earlier.

In 1930, Dubos isolated an enzyme from an unnamed bacillus found in an acidic bog in New Jersey in which cranberry plants were growing. This enzyme destroyed the polysaccharide wall of type III Streptococcus pneumoniae, enabling it to both cure and protect animals infected with this streptococcus (C. L. Moberg René Dubos, Friend of the Good Earth; ASM Press, 2005).

Dubos went on to extract the antibiotics tyrothricin and gramicidin from the soil bacterium Bacillus brevis in 1939. These drugs were produced commercially and used clinically in 1940, before penicillin became available.

Waksman used Dubos' soil-enrichment technique to isolate streptomycin. He later acknowledged Dubos' discovery of gramicidin as "the stimulus which flooded with bright light the whole previously unillumined field of the study and application of antibiotics" (S. A. Waksman in Frontiers in Medicine 99-119; Columbia Univ. Press, 1951). Carol L. Moberg The Rockefeller University, New York, USA. moberg@rockefeller.edu

\section{Rescue Eastern Europe's collections}

The political collapse of Eastern Europe has ravaged its priceless natural history collections. The European Union could rescue many of these as part of its commitment to preserve cultural heritage.

In the small, war-torn nations of the western Balkans, for example, natural history collections receive much less government funding than museums of history, ethnography and archaeology. Ministries of science in countries of the former Yugoslavia dismiss the importance of natural history collections for research infrastructure or as scientific heritage.

Unstable funding forced the Sarajevo museum to close in 2012, and many of its historical specimens - including 10,000 bird skins and 500,000 insects from the Balkans - have not been properly curated for years. And the break-up of the Soviet Union left individual states with little interest in maintaining their collections - including one of the world's most important, at the Zoological Museum in St Petersburg, Russia.

All of these once wellmanaged collections are now decaying, making the plight of Italy's natural history museums the tip of an iceberg (see Nature 515, 311-312; 2014).

Boris Kryštufek Slovenian Museum of Natural History, Ljubljana, Slovenia.

Nataliya Abramson Zoological Institute, Russian Academy of Sciences, St Petersburg, Russia. Dražen Kotrošan National Museum, Sarajevo, Bosnia and Herzegovina.

bkrystufek@pms-lj.si

\section{Tweak Chinese law to end ivory demand}

The proposed revisions to China's wildlife protection law of 1988 should aim to make the private ownership of threatened species illegal. This would help to control the country's flourishing trade in illegal animal products. It is also important to tackle the public's demand for such goods by changing their perceived 'luxury' status.
One of us (Z.-M.Z.) investigated criminal trading in China of ivory, rhino horn and the teeth, bones and pelts of big cats in 2010-13, all products from animals of crucial conservation concern. However, these are much sought after and have a high market value - accounting for roughly half the worth of all 78 species investigated.

Farming or ranching of these animals might present one solution, but could also act as a cover for illegal trading. Better education of the public is needed to drive home the shocking consequences of this trade for biodiversity, and to remove the demand. Coupled with amendments to the wildlife protection law, China would then be taking a major step towards valuing healthy ecosystems above objets d'art and traditional medicine practices.

Zhao-Min Zhou* Yunnan Public Security Bureau for Forests, Kunming, China. zhouzm81@gmail.com ${ }^{*}$ On behalf of 6 correspondents (see go.nature.com/y9f8ui for full list).

\section{'Simple' or 'elegant' criteria are not valid}

Counter to the impression given by George Ellis and Joe Silk, I have never used or endorsed the slogans "elegance will suffice" and "post-empirical science" regarding theories in fundamental physics (Nature 516, 321-323, 2014). In fact, both contradict my position.

I do not think that criteria such as simplicity or elegance provide a workable basis for judging a theory's chances of viability. I seek arguments that are more reliable.

Nor is my concept of nonempirical theory confirmation driven by a wish to declare empirical data obsolete. Rather, it aims to account for the actual situation in modern fundamental physics by extending the concept of theory confirmation while preserving the primacy of empirical data.

A theory's non-empirical confirmation relies on experimental confirmation in three ways. First, a theory's viability is defined in terms of its empirical confirmation. Second, non-empirical confirmation will always remain weaker than conclusive empirical confirmation. And third, non-empirical confirmation relies on the observation that related theories in the field were empirically confirmed.

Terminating empirical confirmation in a research field would thus eventually destroy the basis for non-empirical confirmation as well. Richard Dawid Ludwig Maximilian University of Munich, Germany. richard.dawid@univie.ac.at

\section{Czech centre marks Mendel anniversary}

This month marks the 150th anniversary of Gregor Mendel's presentation of his famous study 'Experiments in plant hybrids' at a meeting of the Nature Research Society in Brno, Moravia (in today's Czech Republic). His lecture was published a year later in the society's journal.

Often called the father of modern genetics, Mendel and his scientific and cultural legacy are being honoured at the Mendelianum Centre of the Moravian Museum, the original premises of the society where his ideas were first formulated and discussed. The centre, which will be officially opened on $8 \mathrm{March}$, is both a Mendel museum and an outreach venue for modern genetics research, science and education (see www.mendelianum.cz). Anna Matalová, Eva Matalová Mendelianum Centre of the Moravian Museum; and Institute of Animal Physiology and Genetics, Brno, Czech Republic. matalova@iach.cz 